特集・新しい川づくりをめざして(2)

\title{
生物の多様な生息・生育環境の確保のために 一多自然型川づくりの推進一
}

1.はじめに

本年 3 月に河川審議会より「今後の河川環境のあり 方について」が答申されました，その中で河川環境の 保全と創造の基本方針の一つとして,『生物の多様な 生息・生育環境の確保が必要である』と述べられてい ます．ここでは，この答申及び，近畿地方建設局管内 で進めている「多自然型川づくり」について紹介します。

\section{2. 河川審議会からの答申}

河川審議会は, 昭和 56 年 11 月に「今後の河川環境 管理のあり方について」を答申しました，それ以降十 数年経過した今日, 新たに課題に対応していくため, 河川環境の保全と創造の基本方針とそのために推進す べき施策について今回答申された。

この中で，『河川環境の保全と創造に関して従来か ら様々な取り組みがなされてきたが，河川環境を巡る 新たな課題への対応を図るためには，以下の施策の推 進が求められている』また，基本施策の一つに『生物 の多様な生息・生育環境の確保のための施策』につい て述べられており，以下に概要を記載します。

\section{1 生物の多様な生息・生育環境の確保のための} 施策

河川環境の保全と創造の関する基本的な事項を定め た河川環境管理計画が水系毎に策定され，生物の生息・ 生育環境などに配慮した河川管理がなされてきた。

また，自然豊かで美しい河川整備を行う「多自然型 川づくり」や,「魚がのぼりやすい川づくり」,ダム貯 水池の周辺の自然環境の再生や創造のための諸施策が 実施されてきた。

こうしたこれまでの取り組みに加えて, 今後は以下 の取り組みを推進する必要がある.

*建設省近畿地方建設局河川計画課 課長補佐 Motoyuki AYAKI
綾 木 基 之*

(1)多様な河川形状の採用

河川の改修に当たっては，洪水を安全に流下させる ことを基本としっつ生物の多様な生息・生育の場を確 保し, 河川の特性や地域の個性にふさわしい川づくり を進める.このため，必要となる河川空間の確保に努 めつつ, 安易な河道の直線化をさけるなど, 河川の形 状にできるだけ変化を持たせる.

(2)流域での自然的広がりを考虑した取り組みの検討

河川, 湖沼, 眝水池は, これにつながる水路や緑の 空間とともに地域における水と緑のネットワークとし ての役割を担っており，この役割をさらに向上させ， 豊かな地域づくりを進める必要がある。このため, 多 様な生物の生息・生育空間としての河川整備, 湖畔林 の形成を目指すなど沿川の緑化を推進する.

(3河川における上下流方向の連続した環境条件の確保 河川を横断する工作物の構造の改善, 魚道の設置・ 改良, 生物の生息に必要な水量の確保等を上流から河 口まで水系全体を考慮しつつさらに推進すること．ま た，河川の高水敷においても生物の生息・生育環境の 連続性に配慮し，生物の自由な移動の確保に努めること. (4)貴重な動植物種の絶滅を防止するための取組みの推進 関係部局との連携を図りつつ，「絶隇の恐れのある 種」として指定された種を始め貴重な動植物種の保護 増殖に資する取組みをさらに推進すること。

(5)「河川水辺の国勢調查」の充実

現在実施している「河川水辺の国勢調査」について, 調查項目, 調查対象河川の拡大等見直しを適宜行い, その充実を図るとともに，その結果が広く利用される ように努めること.

(6)生物の生息・生育環境に支障を与える行為の制限

「河川水辺の国勢調査」の結果等を踏まえ，生物の 生息・生育環境の保全が必要な河川区域を明確にし, その保全に支障を与える行為の制限について検討を行 うこと. 


\section{3. 多自然型川づくり}

平成 2 年に「多自然型川づくり実施要領 を策定し, 今後積極的に推進することとしました.

多自然型川づくりは, 当面は, パイロット的に実施 するあのです，そのため，採用した工法の適用性，実 施前後の比較, 適正な維持管理等について調查研究を 併せて実施し, 我が国の地形, 気像条件に適した「多 自然型川づくり」の確立に向け, その基礎資料の収集 に努めています。

\section{1 多自然型川づくりの基本方針}

多自然型川づくりを実施にあたり次のような基本方 針が考えられます。

(1)多自然型川づくりは, 治水を無視してまでの河川の 環境形成を目標としない，治水面でも環境面でも調 和のとれた河川環境を構築することを前提とする.

(2)川が安定しているかどうかの判断も必要であり, 土 砂移動等を考慮して将来どのような川になるかの検 討が必要である.

(3)強固な河川構造物を必要としない筒所では，その川 の個性を保全あるいは再現することが可能であり， 逆に強固な河川構造物が必要な箇所では生物の生息 や河川景観向上のための配慮が必要となる.

(4)コンクリートの人工物は, 景観を単調かあるいは殺 伐としたものとし，一分のすきもないブロックは土 壌自体の居場所をなくし，食物連鎖のベースとなる 植物の生育を妨げている。

(5)自然の形成は，一朝一夕ではなく，長い年月をかけ て徐々に創り上げられたものであり, 再び元の自然 の状態に戻すには最低限それまでの環境を形成する のに要した年月が必要である. 環境へのダメージを 少なくすることに心がける必要がある.

(6)維持管理の方法とは，「管理をしない（自然管理）」, 「毎年全体を管理する」，「一部のみ管理し逐次順番 に管理していく」等がある.

(7)採用した工法が，どの程度効果があるあのか，どう すれば質的な向上が図れるのかを環境の変化を通し て常に検討することが必要である.

\section{2 実施事例}

多自然型川づくりについて近畿地方建設局管内で実 施した施工例を記載します。なお，これらの実施例は， 必ずしもべストとはいえないものもありますが，参考 にしていただけばと考えます。

(1)河床形態の多様化（淀川水系桂川）

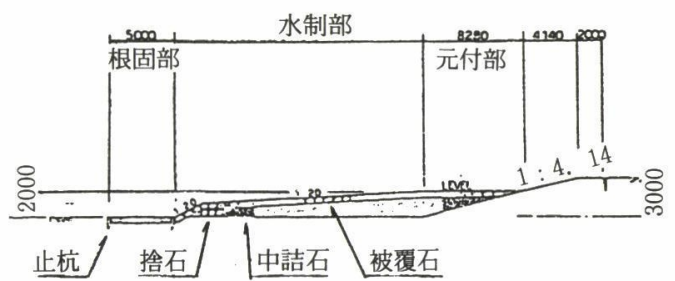

図-1 横断図

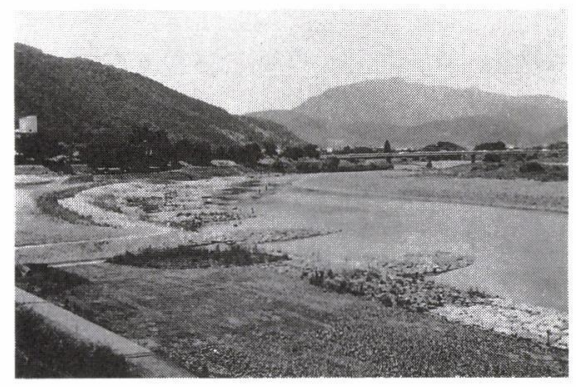

写真 1 施 工 後

(唅石の隙間に魚類が多数見られよい魚巣となっている)

当区間は, 湾曲部の外側で水衝部となり河岸洗掘を 受けやすい箇所である。 そのため, 流速を減速させる 水制工による洗掘防止対策を行った.

なお，砕石による沈床，自然石（1t 程度）の捨石 で河床形態の多様化を図った。

(2)覆土による植生回復（加古川水系加古川)

周辺は, 自然野草地区であり大規模なッルョシ群落

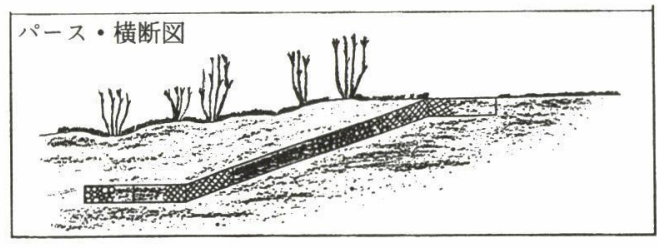

図一2 パース

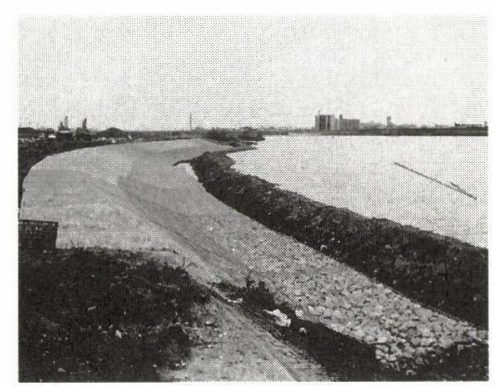

写真 2 施工中（篭マットで護岸を強固なものに してから, 元の土砂で再び覆う) 


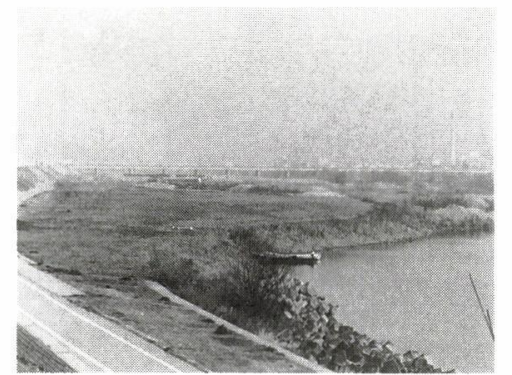

写真 3 施工後（早い時期に元の植生が回復して (る)

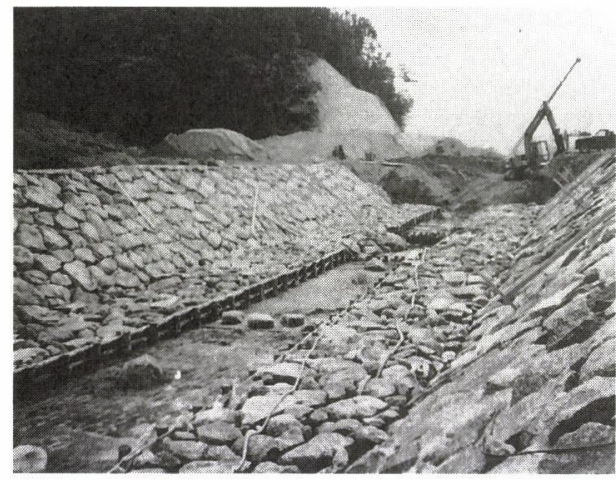

写真 4 施 工 中（低水路に自然石をスポット的に 配置し陰や淵を作った）

あある，そのため，自然野草地植生の現況回復，水生 生物の生育の場及び野鳥営巣の場を提供するために低 水護岸の施工は，篭マットに覆土を行った。

なお，施工後早い時期に元の植生が回復している.

(3)自然石による護岸（円山川水系小野川）

同地区は，放水路の掘削築堤工事箇所です，そのた め河岸は強固な構造にする必要があった.

護岸には, 魚類等の水生生物の生息や, 植物の生育 に配慮して，自然石を用いた。

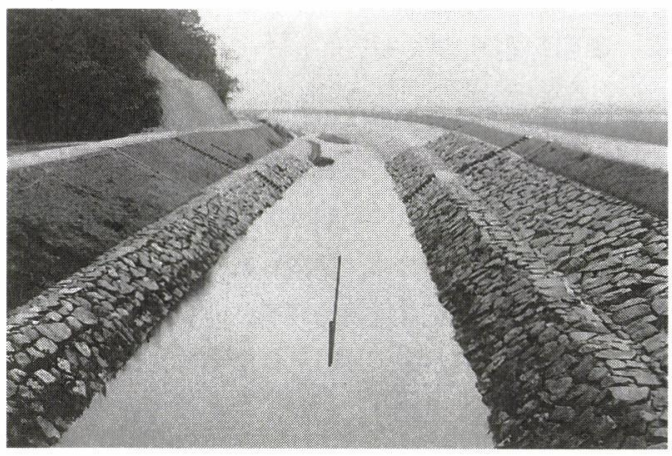

写真 5 施 工 後（護岸には植生が回復し始めている）

\section{4. 魚がのぼりやすい川づくり}

地域のシンボルとなっている河川等において, 堰, 床固め, ダム, 砂防ダム等とその周辺の改良, 魚道の 設置, 改善, 魚道流量の確保等を計画的, 試行的に行 い, 魚類の遡上環境の改善を積極的に行う「魚がのぼ りやすい川づくり推進モデル事業」を実施しています。

このモデル事業は，近畿地方建設局管内においては， 紀の川及び北川が指定されており, 現在実施計画の検 討を行っています。

\section{5.おわりに}

「多自然型川づくり」の積極的な推進を始めて，ほぼ5 年になります。この間，豊かな自然環境，美しい自然な 景観を保全・創出しようとする取り組みは着実に進んだ と思います。しかし，必ずしあ成功例ばかりではなく，また， いろいろな制約によって実施できない箇所むあります。

今後も, 工事例の追跡調査, 伝統的工法の見直し等 の調査研究や, 場所場所に応じた創意工夫を最大限考 えることで『河川整備は多自然型が当たりまえ』に したいと思います。

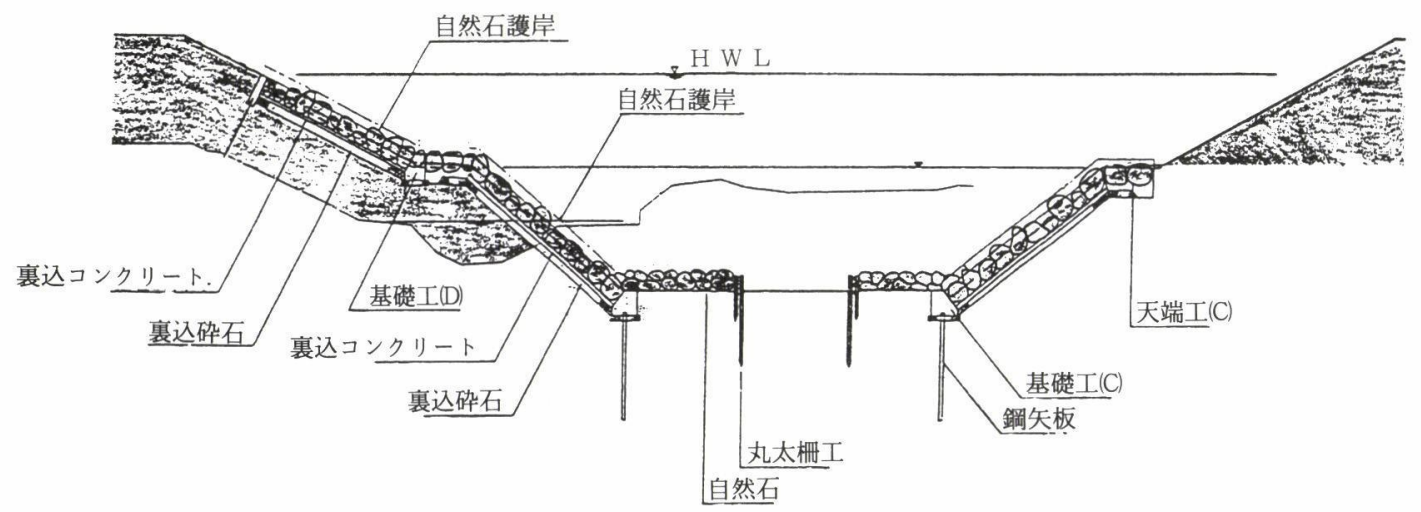

図－3 横 断 図（平水時の流量が少ないので, 水深確保のために低水路に平場を設け，低低水路的な断面とした） 